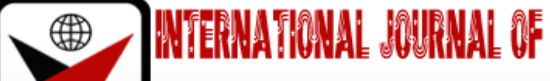

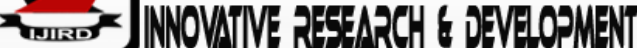

ISSN 2278-0211 (Online)

\section{Determinant of the Development on Capital Structure of Food and Beverage Companies Listed on Indonesia Stock Exchange (IDX) Period 2012-2016}

\begin{tabular}{|c|}
\hline Said Djamaluddin \\
Lecturer, Mercu Buana University, Jakarta, Indonesia \\
Sonia Mutiara \\
Alumni, Mercu Buana University, Jakarta, Indonesia \\
Bambang Marsoem \\
Lecturer, Mercu Buana University, Jakarta, Indonesia
\end{tabular}

Abstract:

This study aims to examine and analyze the determinants of the development of the capital structure of food and beverage companies listed on the Indonesia Stock Exchange (IDX) 2012-2016 period. Research data is secondary data for a 5-year observation period. The sampling method used is purposive sampling. Of the population of 16 food and beverage companies listed on the IDX, 11 companies met the criteria of being a sample. The analytical method used in this study is panel data regression. The results of the study show that firm size and profitability have a significant positive effect, but the structure of assets and liquidity does not affect the capital structure.

Keywords: Asset structure, company size, profitability, liquidity, capital structure

\section{Introduction}

Increasingly sharp business competition causes companies to produce efficiently if they want to compete in this era of globalization. Therefore the company's economy relies heavily on funding, especially for companies that are growing to expand their production markets in achieving a more operational and efficient direction. Companies are required to carry out appropriate funding strategies in determining the most optimal capital structure, namely a condition in which a company can use an ideal combination of debt and capital of the company taking into account the cost of capital that arises.

Capital structure is much influenced by several factors. Factors that influence capital structure are the interest rate, stability of earnings, the composition of assets, the level of risk of assets, the amount of capital needed, the condition of the capital market, the nature of management, and the size of a company (Riyanto, 1999: 296). Some empirical evidence about the factors that influence capital structure is asset structure. The following is a picture of the average DER and asset structure in the food and beverage industry in the IDX in 2011-2015.

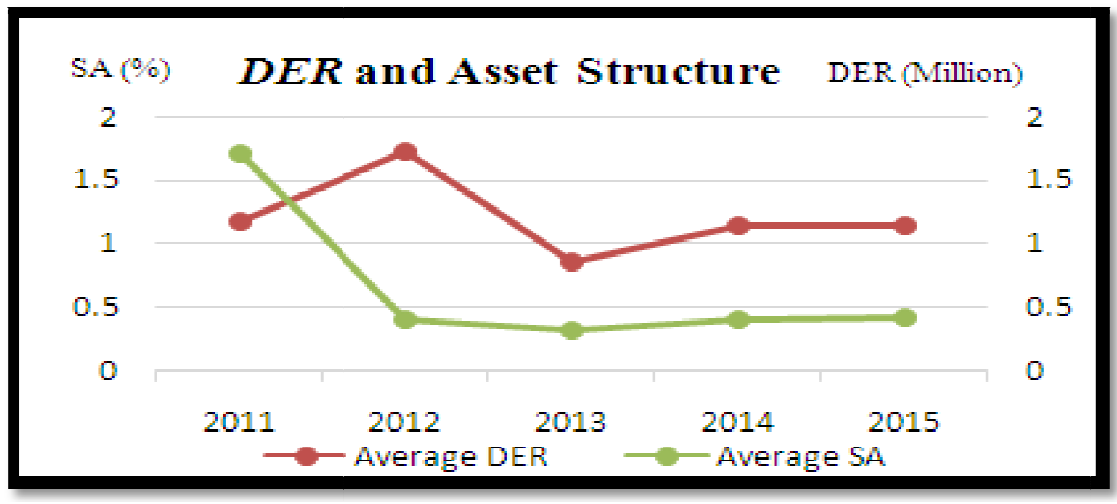

Figure 1: Average Capital Structure and Asset Structure in the Food and Beverage Industry in 2011-2015

Source: Indonesia Stock Exchange 2018 
Figure 1. showed that DER experienced an increase in 2012 and its asset structure declined in 2012, then fell equally in 2013. And rising together in 2014, it turned out that the decline in asset structure did not always decrease DER. This is consistent with research by Danang (2017) that asset structure does not always affect the capital structure.

Company size is one factor that must be considered in the capital structure decision. Large companies have large funding needs to finance company activities and one of the alternatives to meet these funding needs is to use debt. In other words, the size of a company directly affects the company's capital structure policy. The greater the size of a company, the greater the tendency to use foreign capital. This is because large companies need large funds to support their operations.

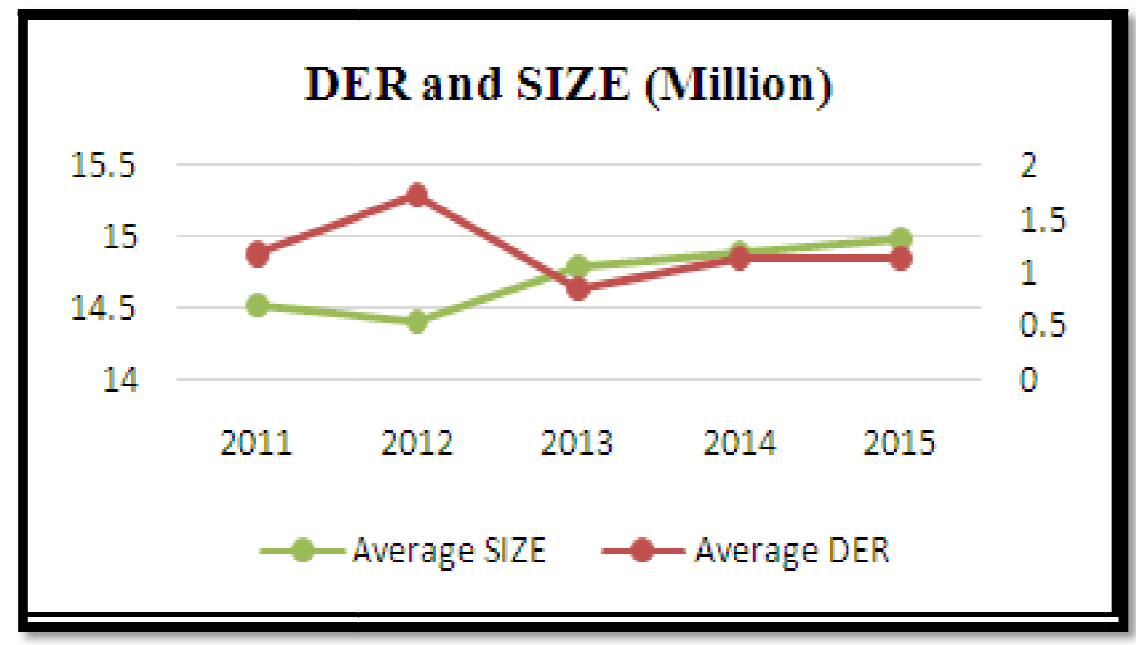

Figure 2: Average DER and SIZE in the Food and

Beverage Industry in 2011-2015

Source: Indonesia Stock Exchange 2018

Figure 2 shows that DER experienced an increase in 2012 and the size of the company declined in 2012, then fell equally in 2013. And rising together in 2013, the decline in company size did not always reduce DER. This is consistent with the research by Okta Saputra (2016) that the size of a company does not always affect the capital structure.

Another determining factor is the aspect of profitability, this aspect is the main attraction for shareholders, because by looking at the profitability aspect investors can see the company's development and to assess the company's prospects in the future, investors can find out how effective the company is by looking ratio Return on Equity. The following is an average picture of Return on Equity (ROE) in the food and beverage industry in the IDX in 2011-2015.

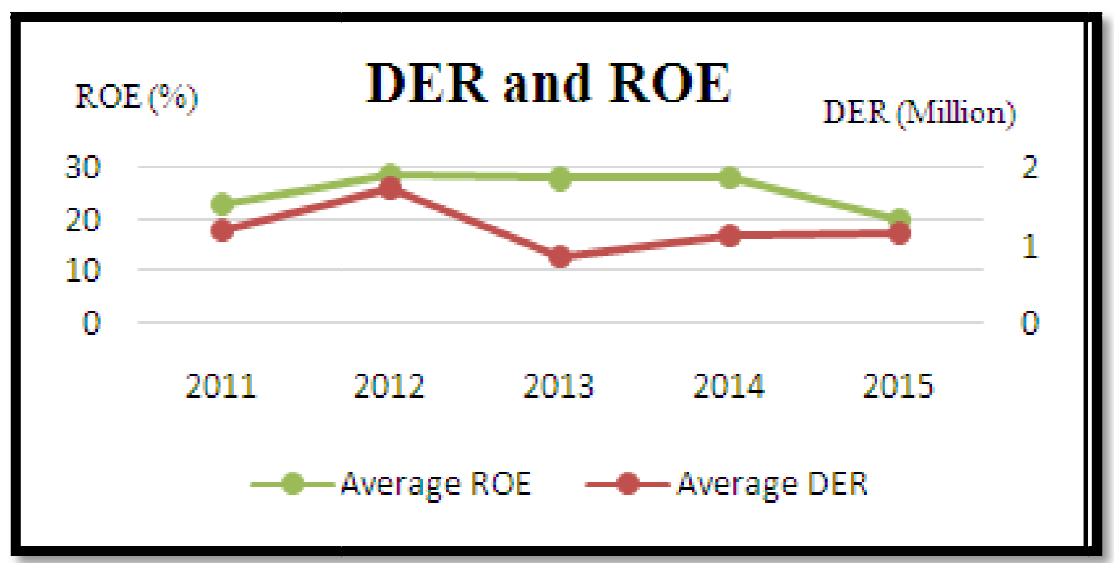

Figure 3: Average DER and ROE in the Food and Beverage Industry in 2011-2015

Source: Indonesia Stock Exchange 2018

Figure 3 showed that DER experienced an increase in 2012 and ROE also experienced a decline in 2012, then both fell in 2013. And rose together in 2013, then dropped again in 2015. It turned out that the decline in company size affected DER. This is consistent with research by Devi Verena Sari et, al (2013) that firm size has an effect on capital structure.

And another determining factor is liquidity, the company's liquidity is a measure of the company's ability to meet its financial obligations that must immediately be met. In this study the level of corporate liquidity is measured by the ratio of Current Ratio. The analysis determined that the current value of the ratio that is good for a company is $2: 1$ or $200 \%$. The following is a picture of the average liquidity (Current Ratio) in the food and beverage industry in the IDX 2011-2015. 


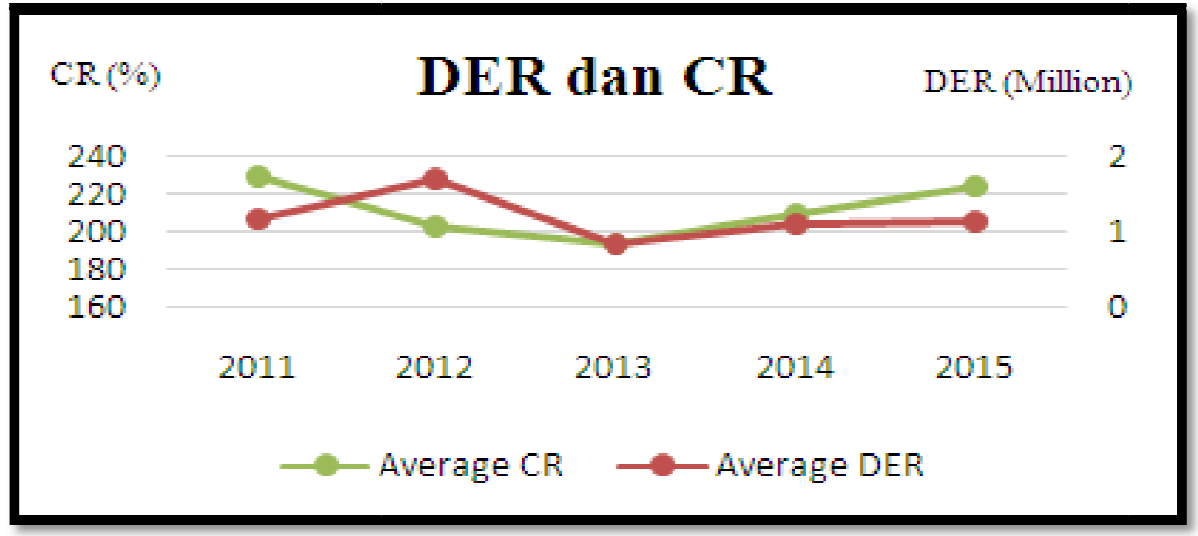

Figure 4: Average DER and ROE in the Food and Beverage Industry in 2011-2015 Source: Indonesia Stock Exchange 2018

Figure 4 shows that DER has increased in 2012 and Current Ratio has decreased in 2012, then in 20132013 both experienced a decline. And rose together in 2014, then both rose again in 2015. It turned out that the decline in liquidity did not always affect the DER. This is consistent with research by Yudiandari (2018) that the size of a company influences the capital structure. Based on the background of the above problems, several problems can be identified as follows: the business world has financial difficulties and many obstacles including funding problems, the need for accuracy in decision making regarding capital structure and the difficulty for managers to determine the most influential factors.

This study aims to see whether the asset structure, company size and profitability have a simultaneous effect on the capital structure of food and beverage companies listed on the Indonesia Stock Exchange for the period 2012-2016.

\section{Literature Review}

\subsection{Mogdialiani Miller Theory}

The irrelevant results of Mogdialiani Miller's theory depend on the assumption that the company will not go bankrupt, so the cost of bankruptcy becomes irrelevant. In fact, every company has the opportunity to experience bankruptcy, it could be the cost of bankruptcy requires a large fee. Bankruptcy will be greater along with the increasing amount of debt the company has in its capital structure. Therefore, the cost of bankruptcy is there to prevent companies from using their debts to excessive levels.

\subsection{Trade off Theory}

Hasan (2006: 6) suggests that trade off theory cannot be used to determine the optimal capital structure of a company. But through this model can provide three important inputs, namely:

- Companies with lower business risks can borrow more without having to be burdened by expected cost of financial distress to obtain tax benefits due to greater debt use.

- Companies that have tangible assets and marketable assets such as real estate should be able to use greater debt than companies that have value primarily from intangible assets such as patents and goodwill. This is because intangible assets are easier to lose value in the event of financial distress, compared to standard assets and tangible assets.

- Companies that pay high taxes (subject to a small tax) should use more debt than companies that pay low taxes (low tax rates).

\subsection{Pecking Order Theory}

Pecking Order Theory is a capital structure theory formulated by Myers and Majluf (1984) which explains why companies will determine funding decisions following a hierarchy of the most preferred source of funds. In accordance with this theory, investment will be funded by internal funding sources, namely retained earnings rather than external funding sources. In the case of using outside funding, loans are preferred over additional capital from new shareholders (Husnan and Pudjiastuti, 2002: 311).

\subsection{Factors Affecting Capital Structure}

The capital structure shown as Debt to Equity Ratio (DER) is a general measure used to see the level of debt to equity. DER is defined as the divider between the total debt and the source of capital. In determining the balance between total debt and own capital reflected in the company's capital structure, it is necessary to consider the distribution of factors that affect the capital structure.

Brigham and Houston (2011), stated that in general companies will consider several factors when making capital structure decisions are sales stability, asset structure, operating leverage, profitability growth rates, taxes, control, management attitudes, lender attitudes and rating agencies, conditions market, internal conditions of the company, and financial flexibility. 


\subsection{Asset Structure}

Asset structure or wealth structure is a balance or comparison both in absolute terms and in the relative meaning between current assets and fixed assets (Riyanto, 1999: 22). Furthermore, what is meant by absolute meaning is comparison in nominal form, while what is meant by relative meaning is comparison in the form of percentage.

According to Sartono (1994), companies with flexible asset structures tend to use more debt than companies whose asset structure is not flexible. Fixed assets will be used as collateral for debt, if the company is not liquid. The asset structure is the wealth or economic resources owned by the company that are expected to provide benefits in the future, which consist of fixed assets, intangible assets, current assets, and non-current assets.

\subsection{Company Size}

Company size can be interpreted as company size seen from the value of equity, company value, or the result of the total value of a company's assets (Riyanto, 2001). According to Sujianto (2001), company size describes the size of the company indicated by the total assets of total sales, the average total sales of assets, and the average total assets. In this study the size of the company is measured through total assets as indicated by the natural logarithm value of the total assets of the company (Ln Total Asset). Company size will affect the capital structure, the larger the company, the greater the funds needed by the company to invest (Ariyanto, 2002). The larger the size of a company, the greater the tendency to use foreign capital. This is because large companies need large amounts of funds to support their operations, and one alternative is to meet foreign capital if their own capital is insufficient (Halim, 2007).

\subsection{Profitability}

Profitability is the company's ability to generate profits and measure the level of operational efficiency and efficiency in using its assets (Chen, 2004). Profitability is an indicator to assess the company's financial performance or ability to generate profits.

Profitability also has an important meaning in the effort to maintain the long-term survival of the company, because profitability indicates whether the company has good prospects in the future. Thus each company will always try to improve its profitability, because the higher the level of profitability of the company, the survival of the company will be guaranteed. According to Sofyan (2010: 304-305), the profitability ratio describes the ability of a company to earn profits through all its capabilities, and available resources such as sales activities, cash, capital, number of employees, number of branches, and everything.

\subsection{Liquidity}

Liquidity ratios are used to measure a company's ability to meet its short-term (or current) short-term obligations available to fulfill these obligations (Van Horne and Wachowicz, 2001). One of the liquidity ratios that will be used in this study is the current ratio.

\subsection{Hypothesis}

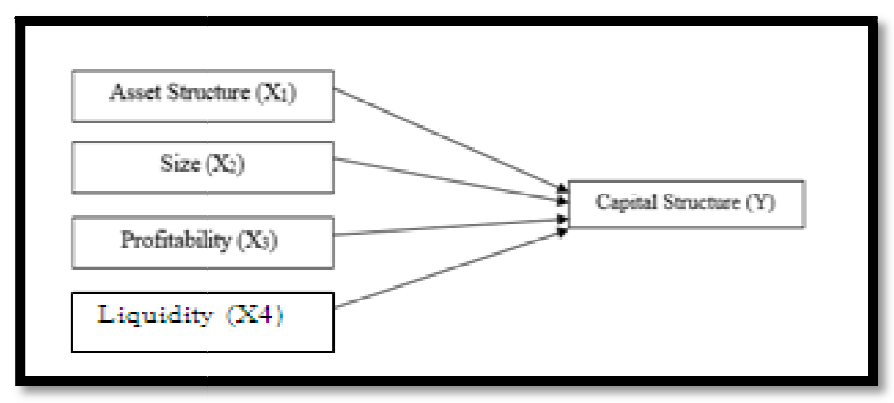

Figure 5: The Framework of Thought

Asset structure or commonly called tangibility of assets is the determination of how much the amount of allocation for each component of assets will reflect the ability or amount of collateral from assets owned by the company on the guarantee that is carried out. According to Naibaho, et al (2015) that asset structure affects the company's capital structure in the property and real estate industry on the Indonesia Stock Exchange. From the conclusions above can be drawn the hypothesis that the asset structure affects the capital structure.

- H1: Asset structure affects capital structure

According to Riyanto (1999: 299) the size of the company describes the size of a company; a larger company will be easier to obtain loans than a small company. The results of this study are supported by Seftianne (2011) which shows that firm size has a positive effect on capital structure. Based on this explanation, it can be concluded that the size of the company has a positive effect on the capital structure. From the conclusions above can be drawn the hypothesis that the size of the company affects the capital structure.

- H2: Company size affects capital structure

Profitability is the net result of a series of policies and decisions (Brigham and Houston, 2011). Profitability

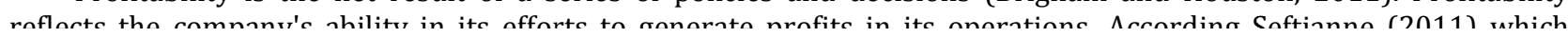


shows the results of research, profitability has a negative effect on the capital structure. It can be concluded that profitability has a negative effect on the capital structure.

- H3: Profitability affects capital structure

According to Pecking order theory, companies that have high liquidity will tend not to use debt financing because they have large funds for internal funding. According to Kharizmatullah (2017) that Current Ratio affects the capital structure. From this explanation, it can be concluded that liquidity affects the capital structure.

- H4: Liquidity affects capital structure.

\section{Research Method}

In accordance with the purpose of the study is to test the hypothesis, the research method used is quantitative. The type of data used in this study is secondary data, namely data obtained in the form that has been finished, has been collected and processed by other parties, usually in the form of publication (Supranto, 1994: 11). The data is in the cross section and time series categories taken in the period of 2012 to 2016 . The population in this study are food and beverage companies listed on the Indonesia Stock Exchange (IDX) respectively during 2012-2016. The sample in this study was selected food companies using purposive sampling method with a total of 11 data samples. The dependent variable used is the capital structure and the independent variables used are asset structure, company size, profitability and liquidity.

\begin{tabular}{|c|c|c|}
\hline Variable & Measurement & Scale \\
\hline Capital Structure $(\mathrm{Y})$ & $\mathrm{DER}=\frac{\text { Total Debt }}{\text { Total Equity }}$ & Rasio \\
\hline Asset Structure $\left(\mathrm{X}_{1}\right)$ & $\mathrm{SA}=\frac{\text { Fixed Asset }}{\text { Total Asset }}$ & Rasio \\
\hline Size $\left(\mathrm{X}_{2}\right)$ & Size $=$ Ln $($ Total Asset $)$ & Rasio \\
\hline Profitability $\left(\mathrm{X}_{3}\right)$ & $\mathrm{ROE}=\frac{\text { EAT }}{\text { owner's equity }}$ & Rasio \\
\hline Liquidity $\left(\mathrm{X}_{4}\right)$ & $\mathrm{CR}=\frac{\text { Current Asset }}{\text { current liablities }}$ & Rasio \\
\hline
\end{tabular}

Table 1: Research Variable

This study uses panel data, while data processing uses EViews version 9. According to Gujarati and Porter (2012: 237) panel data is a combination of time series data and cross section. With the dependent variable used is the capital structure $(\mathrm{Y})$ and the independent variables used are asset structure $\left(\mathrm{X}_{1}\right)$, company size $\left(\mathrm{X}_{2}\right)$, profitability $\left(\mathrm{X}_{3}\right)$ and liquidity $\left(\mathrm{X}_{4}\right)$.

Panel data can be grouped in general into three types, namely:

\subsection{Pooled Least Square (PLS)}

This method is the simplest method. In the estimation it is assumed that each individual unit has the same intercept and slope (there is no difference in the time dimension). In other words, the resulting data panel regression will apply to each individual. (Juanda and Junaidi, 2012: 180).

\subsection{Fixed Effect Model}

In the Fixed Effect Model method, intercepts on regression can be distinguished between individuals because each individual is considered to have its own characteristics. In distinguishing intercepts, a dummy variable can be used, so this method is also known as the Least Squares Dummy Variable model (Juanda and Junaidi, 2012: 180).

\subsection{Random Effect Model.}

According to Gujarati (2003), if dummy variables are to represent ignorance about the actual model, then we can use the disturbance term to represent ignorance about the actual model. This is known as a random effect model (REM or random effect model).

As for testing panel data is divided into 3 ways, namely:

\subsection{Chow Test}

Chow test or some books call it F statistics testing is a test to choose whether the model used is Pooled Least Square or Fixed Effect. In this test the hypothesis is as follows:

- $\mathrm{H}_{0}$ : Common Effect Model

- $\mathrm{H}_{1}$ : Fixed Effect Model

The basis for rejecting the null hypothesis is to use F-statistics as formulated by Chow. This Chow test follows a probability of less than $5 \%$ or a distribution of F-statistics. If the value of the Chow Statistics test (F-Statistic) is greater than $\mathrm{F}$ table, then there is enough evidence to reject the null hypothesis so that the model used is Fixed Effect Model, and vice versa.

\subsection{Hausman Test}

Basically the Hausman test is used to see the consistency of estimation with OLS, so in the panel data modeling, the Hausman test can be used to determine whether to use the Fixed Effect or Random Effect model. The hypothesis used in this test is as follows: 
- $\mathrm{H}_{0}$ : Random Effect Model.

- $\mathrm{H}_{1}$ : Fixed Effect Model.

Using chi square, so if the Hausman test is greater than chi square or the probability is less than $5 \%$ then $\mathrm{H} 0$ is rejected.

\subsection{Lagrange Multiplier Test}

According to Widarjono (2007: 260), to find out whether the Random Effect Model is better than the Common Effect Model, the Lagrange Multiplier (LM) is used. The Lagrange Multiplier test is based on chi-squares distribution with degrees of freedom (df) equal to the number of independent variables. The hypothesis used in this test is as follows:

- $\mathrm{H}_{0}$ : Common Effect Model

- $\mathrm{H}_{1}$ : Random Effect Model

If the Lagrange Multiplier value is greater than the critical value of chi-squares, Ho is rejected, which means that the right model for panel data regression is the Random Effect Model. And conversely, if the calculated Lagrange Multiplier value is smaller than the chi-squares critical value, then Ho is accepted, which means that the right model for panel data regression is the Common Effect Model.

According to Gujarati \& Porter (2009), the equation that meets the classic assumption is only the equation that uses the Generalized Least Square (GLS) method. In EViews, the estimation model that uses the GLS method is only Random Effect Model, while Common Effect and Fixed Effect uses Ordinary Least Square (OLS). Thus the need or not to test the classical assumptions in this study depends on the results of the selection of the estimation method. If based on the selection of the estimation method that is suitable for the regression equation is Random Effect Model, it is not necessary to do a classic assumption test. Likewise in Fixed Effect Model, the classical assumption is tested if there is a dummy variable, if the absence of dummy variables automatically the assumption test has been fulfilled. If the regression equation estimation method is more suitable to use Common Effect (OLS), it is necessary to do a classic assumption test.

The research model equation using the panel data model in this study is as follows:

DERit $=\alpha+\beta 1$ ASit $+\beta 2$ SIZEit $+\beta 3$ ROEit $+\beta 4$ CRit $+\varepsilon$ it

Information:

$\begin{array}{ll}\text { DER } & =\text { Capital Structure } \\ \alpha & =\text { Constants } \\ \beta & =\text { Regression Coefficient } \\ \text { AS } & =\text { Asset Structure } \\ \text { SIZE } & =\text { Company Size } \\ \text { ROE } & =\text { Profitability } \\ \text { CR } & =\text { Liquidity } \\ \text { cit } & =\text { Standard error }\end{array}$

\section{Results and Discussion}

\subsection{Result}

Results from Chow test show results p-value of 0.0013 smaller than 0.05 , then $h_{0}$ is rejected so that the right model is the model. fixed effect. For Hausman test that the probability value shows a value of 0.0766 ( $p$-value $>0.05$ ) then $\mathrm{h}_{0}$ is accepted so that it can be concluded from the Hausman test that the model used is fixed effect. Because the model used is a fixed effect, classical assumptions are not needed. The panel data regression equation obtained as follows: $\mathrm{DER}=-5,0224-0,8528 \mathrm{SA}+0,4369 \mathrm{SIZE}+0,0105 \mathrm{ROE}-0,0014 \mathrm{CR}$

\begin{tabular}{|c|c|c|c|c|}
\hline No & Hypothesis & * Pvalue & Coefficient & Description \\
\hline H1 & Asset Structure has an effect on DER & 0.4980 & -0.8528 & Not significant, H1 Rejected \\
\hline H2 & SIZE has an effect on DER & 0.0146 & 0.4369 & Significant, H2 Accepts \\
\hline H3 & ROE has an effect on DER & 0.0467 & 0.0105 & Significant, H3 Accepted \\
\hline H4 & CR has an effect on DER & 0.1321 & -0.0014 & Not Significant, H4 Rejected \\
\hline
\end{tabular}

Table 2: Hypothesis Testing Results

${ }^{*} P$ Value Standard $\leq 0.05$

\begin{tabular}{|c|c|c|}
\hline & Coefficient & The probability \\
\hline $\mathrm{C}$ & 0.0542 & -5.0224 \\
\hline AS & 0.4980 & -0.8528 \\
\hline SIZE & 0.0146 & 0.4369 \\
\hline ROE & 0.0467 & 0.0105 \\
\hline $\mathrm{CR}$ & 0.1321 & -0.0014 \\
\hline Adj R-square & 0.7100 & \\
\hline F-statistic & 10.4438 & \\
\hline Prob (F-statistic) & 0.0000 & \\
\hline
\end{tabular}


Based on the results using the method Fixed Effect it can be concluded that the company size variable, profitability gives a significant effect while the asset and liquidity structure has no significant effect with the acquisition of probability $<\alpha$ 0.10. For the results of the R-square $\left(\mathrm{R}^{2}\right)$ of this method amounting to 0.7100 , which shows the pooled regression method is able to capture the true picture of the relationship between the independent variable and the dependent variable.

\subsection{Discussion}

Based on the analysis of the research results that have been described in advance, in this section a discussion is conducted to prove the hypothesis. The discussion was carried out by describing the influence between the independent variables consisting of asset structure, company size, profitability and liquidity on the capital structure of food and beverage companies listed on the Indonesia Stock Exchange.

\subsubsection{Effect of Asset Structure to Capital Structure}

Based on the results of data processing EViews 9.0in table 3, the asset structure variable has a p-value of 0.4980 . With a probability level of $90 \%(\alpha=10 \%)$, the value is $<0.10$ so this variable is in the $\mathrm{H}_{0}$ reception area, which means that the asset structure variable is a variable that does not affect the capital structure. Treatment of the direction test found coefficient value of -0.8528 . From this number it can be interpreted that the relationship between the variables DER and the asset structure is the opposite (negative) and insignificant relationship. research with a hypothesis statement made previously by Kharizmatullah (2017) which states that asset structure has a positive effect on capital structure.

\subsubsection{Effect of Company Size to Capital Structure}

Based on the results of data processing EViews 9.0in table 3. Company size variables have a p-value of 0.0146 . With a probability level of $90 \%(\alpha=10 \%)$, the value is $<0.10$ so this variable is in the rejection area of $H_{0}$ which means that the variable size of the company is a variable that has a positive effect on the capital structure. The treatment of direction test found coefficient value of 0.4369 . From this number, it can be interpreted that the relationship between company size variables and capital structure is a direct and positive relationship. This result is not in line with previous research from Okta Saputra (2016) which states that firm size does not affect the capital structure.

\subsubsection{Effect of Profitability to Capital Structure}

Based on the results ofdata processing EViews 9.0in table 3, the company size variable has a p-value of 0.0467 . With a probability level of $90 \%(\alpha=10 \%)$, the value is $<0.10$ so this variable is in the rejection area of $H_{0}$ which means that the variable size of the company is a variable that has a positive effect on the capital structure. Treatment of the direction test found a coefficient of 1.0087. From this number, it can be interpreted that the relationship between company size variables and capital structure is a direct and positive relationship. The results of this study are not in line with the results of previous studies from Suryaman (2016) which states that profitability does not affect the capital structure.

\subsubsection{Effect of Liquidity to Capital Structure}

Based on the results ofdata processing EViews 9.0in table 3, the variable liquidity has a p-value of 0.1321 . With a probability level of $90 \%(\alpha=10 \%)$, the value is $<0.10$ so that this variable is in the $\mathrm{H}_{0}$ reception area, which means that the variable liquidity is a variable that does not negatively affect the capital structure. Treatment of the direction test found coefficient value of -0.0014 . From this number it can be interpreted that the relationship between thevariables DER and the asset structure is the opposite (negative) and insignificant relationship. This is consistent with the research of Okta Saputra (2016) which states that liquidity influences the capital structure.

\section{Conclusion}

The results of testing the data using E Views 9.0 obtained the FEM (Fixed Effect Model), after the F test obtained independent variables together have a significant effect on the dependent variable. With the R-square value $\left(R^{2}\right)=$ 0.7100 shows that $71 \%$ of the variance in capital structure can be explained by changes in the asset structure variables of the company's size and profitability. While the remaining $29 \%$ is explained by other factors outside the model.

Based on the results of the analysis and discussion, then the following is concluded as follows:

- $\quad$ Asset structure variable partially has no significant effect on the capital structure in food and beverage companies listed on the Indonesia Stock Exchange.

- $\quad$ Company size variable partially has a significant positive effect on the capital structure in food and beverage companies listed on the Indonesia Stock Exchange.

- $\quad$ Profitability variables partially have a significant positive effect on the capital structure in food and beverage companies listed on the Indonesia Stock Exchange.

- $\quad$ Liquidity variable partially has no significant effect on the capital structure in food and beverage companies listed on the Indonesia Stock Exchange.

Expressed as follows:

- $\quad$ For food and beverage companies listed on the Indonesia Stock Exchange in maximizing capital structure and preventing bankruptcy at an early stage, it is necessary to consider variables such as company size and profitability because through this study these variables proved to have an effect on the capital structure.

- $\quad$ For academics, this research can be useful for those who want to know how much influence the structure of assets, company size, profitability and liquidity on capital structure in the period 2012-2016. 
- $\quad$ For the government, in making economic policies especially for food and beverage companiesa review is needed so that working capital management in food and beverage companies can be effective and efficient so that it can maintain sustainability and not affect the national economy.

\section{Reference}

i. Ariyanto, T. 2002. "Pengaruh Struktur Kepemilikan terhadap Struktur Modal Perusahaan". Jurnal Manajemen Indonesia. Vol.1, No.1. Universitas Gajah Mada.

ii. Brigham \& Houston (2011).”Dasar-Dasar Manajemen Keuangan”.Buku 2 Edisi 11. Jakarta: Salemba Empat.

iii. Chen, Yingyong dan Klaus Hammes. 2002. Capital Structure. Theories And Empirical Result - A Panel Data Analysis. Cergu S project reports.

iv. Djamaluddin,Said"Analysis the Effect of Npm, Der and Per On Return Share of Listed Company in Jakarta Islamic Index (Jii) Period $2011-2015$

v. Gujarati, DN dan Dawn CP. 2012. Dasar-dasar Ekonometrika. Saduran Sumarno Zain. Salemba Empat. Jakarta.

vi. Halim, A. 2007. Manajemen keuangan bisnis. Bogor: Ghalia Indonesia.

vii. Harahap, Sofyan Syafri. 2010. Analisa Kritis atas Laporan Keuangan. Cet 11. Jakarta : PT Raja Grafindo Persada.

viii. Hasan, M. 2006. Analisis Faktor-Faktor Yang Mepengaruhi Struktur Modal (Studi Pada Perusahaan Yang Terdaftar Di BEJ). Jurnal Tepak ManajerialMagister Manajemen Unri. Vol. 6 No. 6 November

ix. Horne, James C. Van dan John M Wachowicz, Jr. 2012. Prinsip-prinsip Manajemen Keuangan (Edisi 13). Jakarta: Salemba Empat.

x. Juanda, Bambang dan Junaidi. 2012. Ekonometrika Deret Waktu Teori dan Aplikasi. Bogor: IPB Press.

xi. Kharizmatullah, Yuliani, Reza Ghasarma. 2017. Analisis Struktur Modal Perusahaan Industri Makanan Dan Minuman Di Bursa Efek Indonesia. Jurnal Bisnis Dan Manajemen, Volume 1, Nomor 2, Hal 81-88.

xii. Myers, S.C., dan N.S. Maljuf. 1984. "Corporate Financing and Investment Decision When Firm Have Information, Investor Do Not Have",Journalof Financial Economics, 13: 187-221

xiii. Naibaho, T dan Azizah, D.F. 2015. Pengaruh Profitabilitas, Pertumbuhan Penjualan, Struktur Aktiva Dan Ukuran Perusahaan Terhadap Struktur Modal (Studi Kasus Pada Perusahaan Property And Real Estate Yang Terdaftar Di BEI Tahun 2011-2013). Jurnal Administrasi Bisnis (JAB)Vol. 28 No. 1.

xiv. Riyanto, Bambang. 1999. Dasar-dasar pembelanjaan perusahaan (Ed. Ke-4) Cetakan Keenam. Yogyakarta: BPFE.

xv. Riyanto, Bambang. 2001. Dasar-dasar Pembelanjaan Perusahaan. Edisi 4. Yogyakarta: Bagian Penerbitan FE.

xvi. Saputra, Okta. 2016. Pengaruh Ukuran Perusahaan, Return On Equity, Current Ratio, Dan Pertumbuhan Aset Terhadap Struktur Modal Pada Perusahaan Manufaktur Yang Terdaftar Di Bursa Efek Indonesia Periode 2012-2014. Undated.

xvii. Sari, Devi Verena, A. Mulyo Haryanto. 2013. Pengaruh Profitabilitas, Pertumbuhan Aset, Ukuran Perusahaan, Struktur Aktiva Dan Likuiditas Terhadap Struktur Modal Pada Perusahaan Manufaktur Di Bursa Efek Indonesia Tahun 2008 - 2010. Diponegoro Journal Of Management Volume 2, Nomor 3, Tahun 2013, Halaman 1.

xviii. Sartono, Agus. 1999. Manajemen Keuangan Teori dan Aplikasi. Yogyakarta: Bagian Penerbitan FE.

xix. Seftianne. 2011. Faktor-Faktor Yang Mempengaruhi Struktur Modal Pada Perusahaan Publik Sektor Manufaktur. Jurnal Bisnis Dan Akuntansi Vol. 13, No. 1, April 2011, Hlm. 39 - 56.

xx. Sujianto. 2001. Dasar-dasar Manajemen Keuangan. Yogyakarta: BPFE.

xxi. Suryaman, Yurian Ajie. 2016. Pengaruh Profitabilitas, Struktur Aktiva Dan Ukuran Perusahaan Terhadap Struktur Modal Pada Perusahaan Manufaktur Yang Terdaftar Di Bursa Efek Indonesia Tahun 2009-2012. Jurnal Profita Edisi 3.

xxii. Wicaksono, Danang Adi. 2017. Pengaruh Profitabilitas, Likuiditas Dan Struktur Aktiva Terhadap Struktur Modal (Studi Pada Perusahaan Makanan Dan Minuman Yang Terdaftar Di BEI Pada Tahun 2012-2016). Jurnal SimkiEconomic, Vol. 01, No.12, 2017. ISSN: BBBB-BBBB.

xxiii. Yudiandari, Cokorda Istri Diah. 2018. Pengaruh Profitabilitas, Operating Leverage, Ukuran Perusahaan dan Pertumbuhan Penjualan Pada Struktur Modal. E-Jurnal Akuntansi Universitas Udayana Vol.22.1. Januari (2018): 408-437. 